\title{
Canine Filariosis Around Istanbul, Turkey Employing Naphtol AS-TR Phosphatase
}

\author{
M. TOPARLAK, A. GARGILI, M. ULUTAS ESATGIL, H. CETINKAYA \\ Istanbul University, Veterinary Faculty, Department of Parasitology 34851, \\ Istanbul, Turkey
}

Received April 15, 2003

Accepted June 6, 2005

\begin{abstract}
Toparlak M., A. Gargili, M. Ulutas Esatgil, H. Cetinkaya: Canine Filariosis Around Istanbul, Turkey Employing Naphtol AS-TR Phosphatase technique. Acta Vet. Brno 2005, 74: 233-236.

The aim of this study was to find the prevalence of filarial nematodes in dogs in Istanbul, Turkey and identify the species by using naphtol AS-TR phosphatase technique. A total of 286 blood samples were taken from the dogs of different areas of Istanbul, Turkey, between March 1999 and November 2002. The Knott technique was used to detect the microfilariae in blood. Two dogs were found to be positive for microfilariae. The positive blood samples were stained by naphtol AS-TR phosphatase for differentiation. The microfilariae were identified as Dipetalonema reconditum. In this study, differentiation of canine microfilaria based on somatic distribution of acid phosphatase activity was performed for the first time and according to these results $D$. reconditum was reported for the first time from Turkey.
\end{abstract}

Dog, Filaria, Dipetalonema reconditum, Knott-technique, Naphtol AS-TR Phosphatase

Canine filariosis is a nematode disease caused by Dirofilaria spp., Dipetalonema spp. and Brugia spp. in dogs. Among the species D. immitis has a specific importance based on heart localization of adults and it infects also a wide variety of mammals including humans. The differentiation of microfilariae based on morphological peculiarities is difficult and naphtol AS-TR phosphatase technique is the most reliable method for their differentiation. Prevalence of dog filariae has been studied in various countries, in Turkey, no survey on prevalence of filarial nematodes of dog has been encountered except case reports based on finding of adults and morphological identification of microfilariae.

There are many species of filariae in dogs (Table 1). Three of them, Dirofilaria immitis, D. repens (Table 2) and Dipetalonema reconditum (Erdil 1966) have been reported from dogs in various parts of Turkey.

Although the most important host is the dog, D. immitis infects also a wide variety of mammals including human beings (Cheng 1986; Soulsby 1982). In this respect, the species identification of microfilariae is gaining in importance. It is reported that the differentiation of microfilariae based on morphological peculiarities is difficult and naphtol AS-TR technique is the most reliable method for their differentiation. It is based on acid phosphatase enzyme activity in the different body parts of each species of microfilariae (Acevedo et al. 1981; Chalifoux and Hunt 1971; Ortega-Mora et al. 1989; Schrey 1996; Whitlock et al. 1978). In this study, identification of filariid species in dogs was performed and the prevalence was determined in Istanbul for the first time.

\section{Materials and Methods}

This survey was performed between March 1999 and November 2002. A total of 286 blood samples of stray dogs in the various parts of Istanbul were examined for filarial nematodes. All dogs were over 1 year-old and both sexes. About $5 \mathrm{ml}$ blood was drawn from the cephalic vein of each dog (between 10:00 am-05:00 pm) and put into

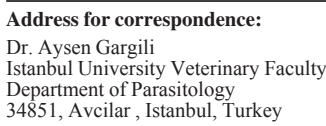

Tel: 902125916979

Fax: 902125916991

902125916976

e-mail: agargili@istanbul.edu.tr

http://www.vfu.cz/acta-vet/actavet.htm 
Table 1. Filarioid nematodes in dogs (Kelly 1979)

\begin{tabular}{|c|c|c|c|c|c|c|}
\hline Species & Host Range & Vector & $\begin{array}{l}\text { Tissue sites } \\
\text { (adults) }\end{array}$ & $\begin{array}{l}\text { Tissue sites } \\
\text { (microfilariae) }\end{array}$ & $\begin{array}{l}\text { Length } \\
\text { of microfilariae } \\
(\mu \mathrm{m})\end{array}$ & $\begin{array}{l}\text { Geographical } \\
\text { distribution }\end{array}$ \\
\hline $\begin{array}{l}\text { Dirofilaria } \\
\text { immitis }\end{array}$ & $\begin{array}{l}\text { Dog, cat, marine } \\
\text { mammals, man }\end{array}$ & Mosquito & $\begin{array}{l}\text { Heart and } \\
\text { pulmonary artery }\end{array}$ & Blood & $\begin{array}{l}286-349 \\
\text { (mean:314) }\end{array}$ & $\begin{array}{l}\text { America, Africa, } \\
\text { Australia, Italy, } \\
\text { Spain }\end{array}$ \\
\hline Dirofilaria repens & Dog, cat, man & Mosquito & $\begin{array}{l}\text { Subcutaneous } \\
\text { tissues }\end{array}$ & Blood & 200 & $\begin{array}{l}\text { USSR, Europe, } \\
\text { India, Far East }\end{array}$ \\
\hline $\begin{array}{l}\text { Dirofilaria } \\
\text { conjunctivae }\end{array}$ & \multicolumn{6}{|c|}{$\begin{array}{l}\text { Considered identical to } D \text {. repens and may also be confused with } D \text {. tenuis, which is found in the subcutaneous tissues } \\
\text { of raccoons and man }\end{array}$} \\
\hline $\begin{array}{l}\text { Dipetalonema } \\
\text { reconditum }\end{array}$ & Dog & Fleas, ticks & Connective tissues & Blood & $\begin{array}{l}258-292 \\
\text { (mean:270) }\end{array}$ & $\begin{array}{l}\text { America, Africa, } \\
\text { Australia, Italy }\end{array}$ \\
\hline $\begin{array}{l}\text { Dipetalonema } \\
\text { dracunculoides }\end{array}$ & Dog & $\begin{array}{l}\text { Louse Fly } \\
\text { (Hippobosca } \\
\text { longifennis) }\end{array}$ & $\begin{array}{l}\text { Peritoneal } \\
\text { membranes }\end{array}$ & Blood & $195-230$ & Africa \\
\hline $\begin{array}{l}\text { Dipetalonema } \\
\text { grassi }\end{array}$ & Dog & Tick & $\begin{array}{l}\text { Subcutaneous } \\
\text { tissues }\end{array}$ & $\begin{array}{l}\text { Skin, rarely in } \\
\text { blood }\end{array}$ & 570 & Italy, Kenya \\
\hline Brugia malayi & Man, cat (dog) & Mosquito & Lymphatic system & Blood & $\begin{array}{l}170-260 \\
(\text { mean:220) }\end{array}$ & $\begin{array}{l}\text { India, Africa, } \\
\text { Far East }\end{array}$ \\
\hline Brugia pahangi & Dog, cat, felidae & Mosquito & Lymphatic system & Blood & 280 & Africa, Far East \\
\hline Brugia patei & Dog, cat & Mosquito & Lymphatic system & Blood & $\begin{array}{l}\text { Similar to } \\
\text { B.malayi }\end{array}$ & Africa \\
\hline
\end{tabular}

Table 2. Filarial nematodes of dogs in Turkey

\begin{tabular}{|c|c|c|c|}
\hline Cities -Years & No of examined dogs & No of infected dogs and species found & Reference \\
\hline Elazg-1983 & 283 (Knott Technique) & $\begin{array}{l}20(7.07 \%) \text { with } \text { D. repens-microfilaria } \\
5(1.77 \%) \text { with D. repens }+ \text { nonspecific-microfilaria } \\
28(9.89 \%) \text { with nonspecific-microfilaria }\end{array}$ & Tasan 1983 \\
\hline Ankara-1983 & 50 (Necropsy) & $2(4 \%)$ with D. repens-adult & Doganay 1983 \\
\hline Elazg-1984 & 120 (Knott Technique) & $\begin{array}{l}1(0.83 \%) \text { with } D \text {. immitis-microfilaria } \\
3(2.5 \%) \text { with } D \text {. repens-microfilaria } \\
6 \text { with } D \text {. immitis-adult } \\
3 \text { with } D \text {. repens-adult }\end{array}$ & Tasan 1984 \\
\hline Eskisehir-1986 & $\begin{array}{l}2 \text { (Necropsy) } \\
20 \text { (Knott Technique) }\end{array}$ & $\begin{array}{l}2 \text { with } D \text {. immitis adult } \\
6 \text { with } D \text {. immitis microfilaria }\end{array}$ & Sarnic 1986 \\
\hline Bursa-1989 & 100 (Necropsy) & $2(2 \%)$ with $D$. immitis-adult & Tinar et al. 1989 \\
\hline Ankara-1989 & 27 (Necropsy) & $3(11.1 \%)$ with $D$. immitis-adul & Zeybek 1989 \\
\hline Konya-1990 & 4 (Necropsy) & 4 with $D$. immitis-adult & Cantoray et al. 1990 \\
\hline Gemlik-1992 & 168 (Knott Technique) & $5(2.98 \%)$ with $D$. immitis-microfilaria & Coskun S.Z. et al. 1982 \\
\hline Van-1992 & 9 (Knott Technique) & 7 with $D$. immitis-microfilaria & \\
\hline & 10 (Necropsy) & 8 with D. immitis-adult & Agaoglu and Sahin 1992 \\
\hline Ankara-1992 & 33 (Necropsy) & $3(9.09 \%)$ with $D$. immitis-adult & Zeybek et al. 1992 \\
\hline Kayseri-1993 & 50 (Necropsy) & $8(16 \%)$ with $D$. immitis-adult & Sahin et al. 1993 \\
\hline Sivas-1997 & 50 (Necropsy) & $3(6 \%)$ with $D$. immitis-adult & Atas et al. 1997 \\
\hline
\end{tabular}

a tube coated with lithium-heparin to prevent coagulation. Knott technique ( Slos s et al. 1994) was used for the detection of microfilariae. When microfilariae were seen, $2 \mathrm{ml}$ of this positive sample was mixed with $12 \mathrm{ml}$ of distillated water to lyse the red blood cells (Rossi and Abbate 1990). This mixture was centrifuged at $1500 \mathrm{rpm}$ for $5 \mathrm{~min}$. Supernatant was discarded and thin smears were prepared from the sediment. Smears were air dried, fixed in absolute acetone for $1-2 \mathrm{~min}$ at $4{ }^{\circ} \mathrm{C}$ and stained with naphtol AS-TR phosphatase (Sigma, St. Louis, USA, Catalog No. N6125) technique (Chalifoux and Hunt 1971). Identification of the microfilariae was done according to Acevedo et al. (1981), Chalifoux and Hunt (1971) and Schrey (1996).

\section{Results}

Two of the $286(0.69 \%)$ examined dogs had microfilariae in their blood. Only one type of microfilariae were observed in smears stained with naphtol AS-TR phosphatase technique. 
The entire body of each microfilaria was stained bright red and higher enzyme activity was noticed between the excretory and anal pore. These microfilariae were identified to be Dipetalonema reconditum.

The dimension of microfilariae varied between 260-290 $\times 4.5-6 \mu \mathrm{m}$ (average: $275 \times 5.25 \mu \mathrm{m}$ ). The districts and the numbers of examined and infected dogs are given in Table 3 .

Table 3. The districts, the numbers of examined and infected dogs and the species found

\begin{tabular}{lcccc}
\hline Districts & No. of examined dogs & No. of infected dogs & Infection rate (\%) & Species found \\
\hline Büyükcekmece & 51 & & & - \\
Haramidere & 20 & & & - \\
Kadiköy & 39 & 1 & 2.27 & Dip. reconditum \\
Ümraniye & 44 & & & - \\
Kemerburgaz & 50 & & & - \\
Zeytinburnu & 14 & & 2 & Dip. reconditum \\
Alibeyköy & 18 & 1 & 0.7 & \\
Sariyer & 50 & 2 & & \\
Total & 286 & & & \\
\hline
\end{tabular}

Discussion

Among many filarial nematodes in dogs (Kelly 1979; Soulsby 1982) mainly 2 species, namely Dirofilaria immitis and D. repens occur in Turkey (Table 2). Although the presence of $D$. reconditum has been reported from one dog, results were based only on the lenght, width and tail morphology of the microfilariae and therefore suspected (Erdil 1966). As it is seen in Table 1, other species are distributed mostly Africa, India and Far East. Adults of canine filariae inhabit the subcutaneous tissue or lymphatic system, only $D$. immitis adults reside inside the heart. Because of the ability of this parasite to infect the human beings in the same pattern, it is the most dangerous species among the dog filariae and its possible public health importance has been discussed in the studies (Atas et al. 1997; D o gan ay 1983) reporting $D$. immitis and conducted in other parts of the Turkey. D. repens and D. reconditum are considered to be non-pathogenic (Acevedo et al. 1981; Kelly 1979; Lindsey 1965; Souls by 1982). Therefore it is very important to make an accurate differential diagnosis of microfilariae of these non-pathogenic species from the pathogenic and zoonotic $D$. immitis. In the previous studies (Agaoglu and Sahin 1992; Coskun et al. 1992; Doganay 1983; Sarnic and Alkan 1986; Tasan 1983; Tasan 1984) performed in Turkey, morphological features and length-width measurements were used for the identification of microfilariae. No doubt that this procedure is time-consuming and difficult whatever technique is employed.

The present findings show that the only species found in dogs in Istanbul was D.reconditum and naphtol AS-TR phosphatase technique based on acid phosphatase activity given an accurate diagnostic criteria since the microfilariae of 3 species of dogs have been reported (Acevedo et al.1981; Balbo and Abate 1972; Chalifoux and Hunt 1971; Whitlock et al. 1978) to have completely different staining pattern. In this study the staining pattern of D.reconditum fits the original description by Chalifoux and Hunt (1971). According to the results of the present study, the major filaria of the dogs in Istanbul is D. reconditum. Although no pathogenic effects have been ascribed to this parasite and also it is not of public health importance compared to $D$. immitis, it is important to accurately diagnose and differentiate its microfilariae from those of $D$. immitis, in the diagnosis of heartworm infections.

\section{Výzkum fillariózy u psů v okolí Istanbulu pomocí naftol AS-TR fosfatázové techniky}

Cílem studie bylo zjistit prevalenci filárií u psů v okolí Istanbulu a určit jejich druh pomocí naftol AS-TR fosfatázy. Od března1999 do listopadu 2002 bylo odebráno celkem 286 vzorků krve psů z různých oblastí Istanbulu. K detekci mikrofilarií v krvi byla použita 
Knottova metoda. Test byl pozitivní u dvou psů. Pozitivní krevní vzorky byly k diferenciaci obarveny naftol AS-TR fosfatázou. Mikrofilárie byly identifikovány jako Dipetalonema reconditum. V této studii byly poprvé v Turecku mikrofilárie diferencovány na základě somatické distribuce aktivity kyselé fosfatázy, identifikovány jako D. reconditum.

\section{References}

ACEVEDO RA, THEIS JH, KRAUS JF, LONGHURST WM 1981: Combination of filtration and histochemical stain for detection and differentiation of Dirofilaria immitis and Dipetalonema reconditum in the dog. Am J Vet Res 42: 537-540

AGAOGLU ZT, SAHIN A 1992: Van'da Dirofilaria immitis (Dirofilaria immitis in Van). YY Üniv Vet Fak Derg 3(1-2): 117-121

ATAS AD, ÖZCELIK S, SAYGI G 1997: Sivas sokak köpeklerinde görülen helmint türleri, bunlarin yayilisi ve halk sagligi yönünden önemi (The occurrence of Helminth Species in Stray Dogs, Their Prevalance and Significance of Public health in Sivas). T Parazitol Derg 21: 305-309

BALBO T, ABATE O 1972: Histochemical differentiation of microfilariae of Dirofilaria immitis, Dirofilaria repens and Dipetalonema sp. Parassitologia 14: 239-244

CANTORAY R, DIK B, GÜLBAHCE S 1990: Konya'da dört köpekte saptanan Dirofilaria immitis (Leidy, 1856) olgusu (Quatre cas de Dirofilaria immitis (Leidy,1856) chez les chiens de Konya). Veterinarium 1: 32-34

CHALIFOUX L, HUNT RD 1971: Histochemical differentiation of Dirofilaria immitis and Dipetalonema reconditum. J Am Vet Med Assoc 158: 601-605

CHENG TC 1986: General Parasitology. 2th ed. Academic Press, Florida, pp. 544-547

COsKUN sZ, TINAR R, AKYOL cV 1992: Dogal enfekte köpeklerde Dirofilaria immitis mikrofilerlerine ivermektinin etkisi (Efficacy of Ivermectin Against Dirofilaria immitis Microfilariae in Naturally Infected dogs). UÜ Vet Fak Derg 11: 121-128

DOGANAY A 1983: Ankara köpeklerinde görülen helmint türleri, bunlarin yayilisi ve halk sagligi yönünden önemi (Prevalence of Helminths in Ankara dogs and their potential public health significance). AÜ Vet Fak Derg 30(4): 550-561

ERDIL, N 1966: Köpeklerde Dirofilaria immitis ve Dipetalonema reconditum üzerinde arastirma (A Study on Dirofilaria immitis and Dipetalonema reconditum in dogs). K.K.K. As. Vet. Akademisi, Iç Hastaliklar Sube ve Klinigi Çalismalari, Ankara

KELLY JD 1979: Canine heartworm disease. Current Veterinary Therapy VII. W.B. Saunders, 326-335 pp.

LINDSEY JR 1965: Identification of canine microfilariae. J Am Vet Med Assoc 146: 1106-1114

ORTEGA - MORA LM, GOMEZ BAUTISTA M, ROJO - VAZQUEZ FA 1989: The acid phosphatase activity and morphological characteristics of Dipetalonema dracunculoides (Cobbold, 1870) microfilariae. Vet Parasitol 33: $187-190$

ROSSI L, ABATE O 1990: Acid phosphatase activity in microfilariae of Setaria labiato - papillosa and comparison with other blood microfilariae of dog and horse origin. Parassitologia 32: 339-342

SARNIÇ H., ALKAN M. 1986: Köpeklerde Dirofilariasis immitis olgulari ve insan sagligi yönünden önemi (Dirofilaria immitis in dogs and its importance for public health). T Parasitol Derg 1-2: 169-174

SCHREY C.F. 1996: Epidemiologische Fallanalyse und klinik der kardiovaskularen Dirofilariose (Herzwurmerkrankung) bei Hunden in Deutschland. PhD Thesis, Freie Universität Berlin, Berlin, Journal Nr. 1942, 125 pp.

SLOSS MW, KEMP RL, ZAJAC AM 1994.: Veterinary Clinical Parasitology 6th ed. Iowa State University Press, Iowa, pp. 107-108

SOULSBY EJL 1982: Helminths, Arthropods and Protozoa of Domesticated Animals 7th ed. Bailliere Tindall, London, pp. 307-320

SAHIN I, EKINCI N, SEN I, ÖZCAN M, GÖDEKMERDAN A 1993: Kayseri yöresi köpeklerinde Echinococcus granulosus (Batsch, 1786) ve diger parazitlerin yayilisi (The distribution and prevalence of Echinococcus granulosus (Batsch, 1786) and other parasites in dogs in Kayseri region). T Parazitol Derg 17: 69-76

TASAN E 1983: Elazig ve yöresindeki köpeklerde filarialarin yayilisi (The distribution of Filariasis in Elazig and its vicinity). Doga Bilim Derg 7: 63-70

TASAN E 1984: Elazig kirsal yöre köpeklerinde helmintlerin yayilisi ve insan sagligi yönünden önemi (The distribution and public health significance of dog helminths in rural districts of Elazig). Doga Bilim Derg. 8: 160-167

TINAR R, COSKUN SZ, DOGAN H, DEMIR S, AKYOL ÇV, AYDIN L 1989: Bursa yöresi köpeklerinde görülen helmint türleri ve bunlarin yayilisi (Prevalence of helminths in Bursa stray dogs). T Parazitol Derg 13: 113-120

WHITLOCK HV, PORTER CJ, KELLY JD 1978: The PKW acid phosphatase modification for the recovery histochemical identification of microfilariae of Dirofilaria immitis in blood. Aust Vet Practitioner 8: 201-207

ZEYBEK H 1989: Ankara yöresi köpeklerinde Dirofilaria immitis olgulari(Les incidences Dirofilaria immitis chez les chiens de la region d' Ankara). Etlik Vet Mikrobiyol Derg 6: 1-9

ZEYBEK H, TATAR N, TOKAY A 1992.: Ankara yöresi kirsal alan köpeklerinde görülen parazitler ve bunlarin yayilisi (The parasites seen in the rural dogs in Ankara region and their distribution). Etlik Vet Mikrobiyol Derg 7: 17-27 
Plate X

Toparlak M. et al.: Canine filariosis ... pp. 233-236

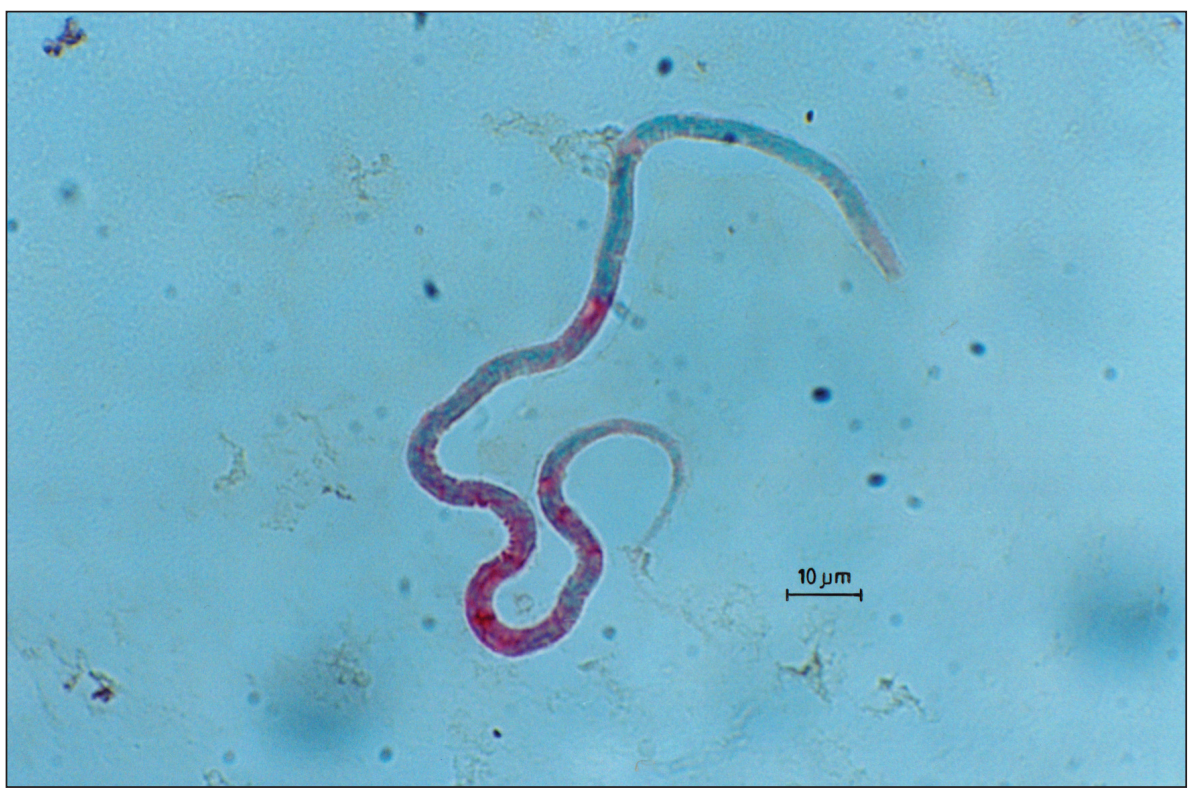

Fig. 1. Pink-stained microfilaria of Dipetalonema reconditum with naphtol AS-TR phosphatase technique 